\title{
A Review of Current Conceptual Research on Short Stories Use in EFL Classrooms
}

\author{
Parlindungan Pardede \\ parlpard2020@gmail.com
}

Universitas Kristen Indonesia

\begin{abstract}
Literature use in EFL learning and teaching has regained great attention in the last decades, and among all literary genres, short stories are regarded the most effective to fuse in EFL classrooms. Conceptual research exploring the use of short stories has significantly increased. However, reviews identifying the insights and ideas concerning the what, why, and how of using short stories in EFL classrooms in these articles are still rare. Thus this paper aimed to review 14 conceptual research published in 2011-2020 and indexed in Google Scholar focusing on short stories use in EFL learning and teaching to draw a general picture of the underlying reasons and difficulties in using short stories, considerations for selecting short stories, and how to exploit short stories in the classroom. Based on the analysis employing the constant comparative method, this paper reports the results. After discussing the findings, some suggestions are recommended.
\end{abstract}

Keywords:

conceptual research, EFL, short story, teaching methods and strategies

How to cite:

Pardede, P. (2021). A Review of Current Conceptual Research on Short Stories Use in EFL Classrooms. Journal of English Teaching, 7(1), 31-42. DOI: https://doi.org/ 10.33541/jet.v7i1.2595 


\section{INTRODUCTION}

After being ignored in about two decades, literature use in EFL learning has regained great attention since the 1980s. Under the domination of Structuralism, Direct Method, Audiolingualism, Community Language Learning, Suggestopedia, Silent Way, Total Physical Response, Natural Approach, and Communicative Approach in 1960 to 1980, literature use in EFL classrooms was questioned. These language teaching approaches and methods tend to regard a foreign language teaching mainly as a matter of linguistics directed to grammatical form correctness mastery, listening and speaking skills acquisition, or oral communication skills proficiency by providing students with usable, functional, and "practical" contents, particularly in the form of dialogues. Consequently, literary works were disregarded in the EFL curriculums in these eras. However, due to the latest global changes and supported by recent research, literature regained its importance in EFL classrooms.

Current views on the EFL field accentuate that the core objective of EFL learning and teaching is not only to facilitate students to master English language components but to facilitate them to establish intercultural communicative competence (Liu, 2003). In other words, the main goal of EFL teaching is to enable students to use the language in socially and culturally appropriate ways. To achieve this, besides linguistic competence and verbal communication skills, students should also be equipped with sociocultural awareness and intercultural skills, and this could be well facilitated by using literary works in the classrooms because they are .valuable authentic materials, offer cultural enrichment, facilitate language development, and increase personal involvement (Collie \& Slater, 1991). Additionally, literature use in EFL classrooms develops communicative competence, cultivates cross-cultural awareness, and create more enjoyable, interesting, and encouraging learning (Ghosn, 2002; Savvidou, 2004), equips students cultural competence, and give them culturally-apposite pragmatic and socio-psychological components (Sell, 2005), hones critical thinking (Parkinson and Thomas 2000; Ghosn, 2002) and advances aesthetic appreciation (Bretz, 1990). Due to its huge potentials to support various aspects of foreign language development, The Modern Language Association of America (2007) recommended a curriculum "in which language, culture, and literature are taught as a continuum" (p. 3).

Among all literary genres, short stories are regarded as the most effective ones to facilitate EFL learning and teaching due to various reasons. First, short stories could be used more comfortably. Unlike poetry which is generally condensed with imageries, connotative words, and figurative languages, most expressions included in a short story are daily languages. This enables students to deal with them on their own. Short stories are also much shorter than novels, and their plots are relatively easier to sum up. They also include a limited number of characters. Therefore, a short story could be done in a few class sessions. Moreover, unlike a play that necessitates much preparation to act out, covering a short story requires only the text. Secondly, short stories are about human experiences, and most of them concern with ordinary life. Therefore, students can familiarize themselves with them quite easily. Third, short stories cover various topics, styles, and themes. This offers teachers an ample opportunity for teachers to select works that suit their students' needs, interests, and tastes. Fourth, short stories are the "best" works using language as the media. They offer good examples of vocabulary and grammatical structures use in contexts and cultural information about the target language that provides teachers a large opportunity to cultivate "an awareness of, and sensitivity towards, the values and traditions of the people whose language is being studied' (Tucker 
\& Lambert, 1972, p. 26) among the students. Murdoch (2002, p. 9) accentuated: "short stories can, if selected and exploited appropriately, provide quality text content which will greatly enhance ELT courses for learners at intermediate levels of proficiency."

Although their use offers various supporting factors to help the development of various aspects of EFL learning and teaching, many EFL teachers are still reluctant to integrate short stories into their classrooms due to their insufficient preparation for the literature integration, lack of clear objectives concerning literature role, deficiency in necessary background knowledge and training in literature, and unavailability of pedagogically-well-designed materials (Ganakumaran et al, 2003; Lima, 2010; Khatib \& Nourzadeh, 2011). Consequently, many teachers encounter difficulties in selecting suitable short stories to meet their students' needs, interests, and language levels and are uncertain how to use short stories in the classroom.

To address these problems this article aims at reviewing the most current conceptual articles on short stories use in the EFL classroom. Hopefully, the results of this review can provide EFL teachers with insights and ideas to cope up with some challenges they meet in using literature in their classrooms. Regarding this, this review aims at finding the answers to the following questions:

1. What reasons do the current conceptual articles on short stories use in EFL classrooms provide for short stories use in EFL classroom?

2. What do these articles reveal about the difficulties encountered in using short stories in the EFL classroom?

3. What do these articles say about how to select short stories that meet students' needs and interests?

4. Does it matter if EFL teachers use local short stories instead of native ones?

5. What do these articles reveal about the methods, strategies, and activities for using short stories in the EFL classroom?

\section{REVIEW METHOD}

This review was carried out by employing the constant comparative method, or the method that "combines systematic data collection, coding, and analysis with theoretical sampling [in order] to generate theory that is integrated, close to the data, and expressed in a form clear enough for further testing". (Conrad et al, as cited in Kolb, 2012, p. 83). According to Glaser \& Strauss (1967, as cited in Kolb, 2012, p. 83), the method includes four stages: (1) comparing incidents applicable to each category, (2) integrating categories and their properties, (3) delimiting the theory, and (4) writing the theory."

In this study, the constant comparative method was carried out in four steps: (1) examining the first selected article; (2) noting its content to form a tentative theme (focus and results); (3) reading the second article; and (4) comparing it to the theme of the first article. If the theme of both articles is similar, the third article was taken and scrutinized. If the theme of the first and second article was found dissimilar, another theme was created. The review then continued by scrutinizing the next article comparing it to the previous ones. Accordingly, each article was examined and compared to another.

The conceptual articles were selected based on four criteria. First, the articles are conceptual papers on short stories use in EFL learning and teaching (empirical research papers were excluded because, to my knowledge, current empirical research seldom focused on short story selection and method and activities for using short stories in EFL classroom). Second, articles include the essential components of conceptual articles. 
Third, they are accessible online and indexed in Google Scholar site. Fourth, to ensure their recency, they were published in the last decade (2011-2020).

\section{FINDINGS AND DISCUSSION}

Employing the four criteria for the selection of the articles, 14 articles were selected (See the Appendix). Some of the articles (Pathan, 2013; Krishna \& Sandhya, (2015); Sholichah \& Purbani, 2018) focus merely on the benefits of using short stories in the EFL classroom. Others (Pardede, 2011, Kaya, 2014; Turan, \& Colak, 2018), besides the benefits of using short stories, describe essential considerations for selecting short stories. The papers that do not discuss the reasons and significances of using short stories are Rabbidge (2013) and Yurtbaş1 (2016). Some of the articles (Thapaliya, 2012; Rabbidge, 2013; Tso, 2014) deal merely with specific teaching methods or strategies for using short stories. Others (Pardede, 2011; Saha, 2014; Yurtbaş1, 2016; Khatib \& Seyyedrezaei, 2017; Turan, \& Colak., 2018; Yunita \& Machdarifah, 2018), besides discussing the benefits of using short stories, also describe teaching methods and learning activities for exploiting short stories. Additionally, the majority (11 or 79\%) of the articles concern with using English (or native) short stories in general. Two others (14\%) discuss using local short stories, i.e. using Indonesian short stories translated into English in the EFL classroom in Indonesian context (Alamsyah, 2016) and using the English version of Dede Korkut's tales in EFL classroom in Turkish context (Yurtbaş1, 2016). One (7\%) deals with fairy tales use in young learners EFL classroom (Sholichah \& Purbani, 2018).

Based on the identification of their contents above, as a whole, the selected articles discuss four themes: (1) multidimensional benefits of using short stories in EFL classrooms (2) how to select short stories; (3) issues in using local short stories in EFL classrooms; and (4) teaching method or strategies and activities for using short stories. The themes and their sub-themes are listed in Table 1.

Table 1.

Emergent Themes and Sub-Themes Based on the Analysis of the Articles' Contents

\begin{tabular}{|c|c|}
\hline Themes & Sub-Themes \\
\hline $\begin{array}{l}\text { 1. Reasons and benefits of using short } \\
\text { stories in EFL classrooms }\end{array}$ & $\begin{array}{l}\text { a. Reasons for using short stories (as a literature genre) in EFL } \\
\text { classrooms } \\
\text { b. Short stories as the most suitable literature genre to use in EFL } \\
\text { classrooms }\end{array}$ \\
\hline 2. How to select short stories & a. Considerations for choosing short stories \\
\hline $\begin{array}{l}\text { 3. Issues in using specific or local short } \\
\text { stories in EFL classrooms }\end{array}$ & $\begin{array}{l}\text { a. Using fairy tales to develop EFL young learners' language skills } \\
\text { d. Using local short stories in Indonesian EFL context } \\
\text { c. Using Turkish tales to explore Turkish culture and improve English } \\
\text { Turkish EFL learners' speaking skills }\end{array}$ \\
\hline $\begin{array}{l}\text { 4. Teaching methods/strategies and } \\
\text { Learning Activities for using short } \\
\text { stories }\end{array}$ & $\begin{array}{l}\text { a. Pre-, while, and post-reading method } \\
\text { b. Linguistic and literary analysis technique } \\
\text { c. Short story based language teaching (SSBLT) } \\
\text { d. Task-based extensive reading teaching approach. } \\
\text { e. Eclectic and practical activities for exploiting short stories } \\
\text { f. Critical thinking strategies to teach short stories }\end{array}$ \\
\hline
\end{tabular}




\section{Reasons for Using Short Stories in EFL Classrooms}

The first theme of the findings concern with reasons for using short stories in EFL classrooms. This theme answers the first research question "What reasons do the current conceptual articles on short stories use in EFL classrooms provide for short stories use in EFL classroom?" This theme includes two subthemes: reasons for using short stories (as a literature genre) in EFL classrooms and short stories as the most suitable literature genre to use in EFL classrooms.

As described earlier, only two out of the 14 articles do not include the underlying reasons and significances of using short stories in EFL classrooms. Three of the articles (Pathan, 2013; Krishna \& Sandhya, 2015; Sholichah \& Purbani, 2018) focus on these issues, while three others (Pardede, 2011, Kaya, 2014; Turan, \& Colak, 2018) elaborate them and seven others (Thapaliya, 2012; Rabbidge, 2013; Saha, 2014; Tso, 2014; Alamsyah, 2016; Khatib \& Seyyedrezaei, 2017) mention them in their introduction sections. Overall, these articles describe that using short stories (and other literary genres as well) in EFL classrooms are beneficial as they offer countless pedagogical benefits for EFL teachers and learners because they naturally have linguistic, socio-cultural, personal and emotional, and cognitive benefits are five foremost advantages.

As the best art using language as its medium, short stories have infinite linguistic benefits embedded in their use in the classroom. Short stories can be the best vehicle to develop the overall language skills of students because, unlike any other informational materials, short stories stimulate the acquisition development as they afford authentic contexts for processing new language. Short stories were written for native speakers, and this enables them to serve as authentic materials for exposing EFL students to rich and authentic language. Such exposure helps the students 'appreciate the richness and variety of the language and become more sensitive to the features of it' (Pardede, 2011) which, in turn, will enable them to develop and integrate the overall language skills in authentic communication.

Short stories also transmit culture, including values, principles, morality, and common-sense. In this context, the sociocultural advantages of using short stories are two-folds. First, by using native speakers' short stories, students will learn essential cultural aspects of the target language. Native short stories enable students to see a world through another's eyes, observe human norms, values, principles, and ideologies, and discover how social, political, historical, cultural events happen in different societies. This will inculcate intercultural awareness which will nurture their skill to interpret discourse in diverse, social and cultural, target language contexts. Second, by using local short stories (in the English version) students will be provided with language learning and better understanding of their own culture. It can even rejuvenate their national pride and values (Pathan, 2013).

Short stories are also effective to develop personal and emotional growth. While reading or listening to short stories, students are provided with various virtuous behaviors they can imitate. They may even put themselves into their hero or heroine's shoes. Students also can learn from the characters' complicated suffering and struggles. Facing the conflicts, struggles, and other unique conditions in stories that reflect the complex array of human situations, students will be encouraged to consider and increase a better understanding of their own lives and build their motivation and personal development.

Last but not least, short stories offer cognitive benefits because short story reading encourages cognitive and learning strategies development. While reading or listening to a story, students will attempt to predict and guess to get the meaning. They will also try

Pardede: A Review of Current Conceptual Research on Short Stories Use in EFL Classrooms DOI: https://doi.org/10.33541/jet.v7i1.2595 
to relate the story to other available external references that will help them get a deeper meaning. At the secondary or higher class level, students will also research external sources to understand something difficult for them. Predicting, guessing, and researching are crucial and essential cognitive and learning skills in developing foreign language competence. Short stories are also entertaining (a necessary condition for decreasing prevalent anxiety and boredom). Moreover, promote critical thinking, because students should reflect, infer, analyze, and synthesize the information presented through both literal and implied expressions commonly included in short stories. Reflecting, inferring, analyzing, and synthesizing information are fundamental critical thinking skills.

Although all literature genres offer all benefits previously described, the reviewed articles indicate that short stories have some special features that make them the most suitable genre to use in EFL classrooms. Overall, short stories' special features discussed in the articles include their simplicity and practicality, shortness, and variety of subject matters, themes, and style (Pardede, 2011; Saha, 2014; Krishna \& Sandhya, 2015; Yunita \& Machdarifah, 2018)

Short stories are practical because, unlike poetry which extensively uses figurative languages, most short stories use simple daily expressions (languages), enabling students to deal with them without significant difficulties. Short stories typically use both dialogues and statements, so that they can practically be used as models for conversation and grammatical practices. Additionally, different from drama which necessitates quite many preparations to act on stages, short stories need only the text to read or the recording to listen to.

Compared to novels, short stories are much shorter. As "a narrative that can be read at one sitting of from one-half hour to two hours, and that is limited to 'a certain unique or single effect" (Abrams, 1970, p. 158, as cited in Pardede, 2011), a short story relatively short so that it is possible to be wholly covered in one or two class sessions.

Short stories also cover so diverse subject matters, themes, and styles. This provides teachers a huge opportunity to choose stories to meet the students' needs, interests and preferences. That's why short stories can meet the needs and interests of students of all ages and all levels of language proficiency.

\section{Considerations for Choosing Short Stories}

The second theme of the findings concern with how to select short stories, and it answers the third research question: "What do these articles say about how to select short stories that meet students' needs and interests?"

The reviewed papers in this study reveal that story selection is one of the teachers' most important roles in using short stories to teach English because some short stories include unfamiliar vocabulary (archaic, slang, and foreign words) and figurative languages (metaphors, allusions, etc.). Short stories may also use complicated and deviated sentences. For students below the intermediate level, short stories using such difficult vocabularies and sentences should be avoided. As a practical guide, the articles recommend teachers to (1) choose short stories whose length makes it possible to wholly cover within course hours; (2) select short stories whose vocabulary and syntactic structure fit the students' level; (3) put Hill's (1994) criteria for choosing short stories into consideration, i.e.: (a) suit the stories to students' needs and abilities; (2) suit the stories' linguistic and stylistic level to the students' proficiency level; and (3) make sure that the amount of background information required for a true appreciation of the material is appropriate.

Pardede: A Review of Current Conceptual Research on Short Stories Use in EFL Classrooms DOI: https://doi.org/10.33541/jet.v7i1.2595 


\section{Issues in Using Specific or Local Short Stories in EFL Classrooms}

The third theme of the findings concern with issues in using specific or local short stories in EFL classrooms, which answers the fourth research question: "Does it matter if EFL teachers use local short stories instead of native ones?" Three subthemes contributed to this theme: using fairy tales to develop EFL young learners' language skills, using local short stories in Indonesian EFL context, and using Turkish tales to explore Turkish culture and improve English Turkish EFL learners' speaking skills.

Fairy tales are regarded as a type of children's literature. They use simple-vivid concrete and practical language with easy grammatical patterns and familiar words. Therefore, they are highly recommended to use EFL young learners. Since they offer the opportunity for developing language skills and language areas and entertainment, they are a potential resource for EFL classrooms (Sholichah \& Purbani, 2018).

If the use of native short stories facilitates students to learn the essential cultural aspects of the target language necessary to inculcate intercultural awareness, the use of local short stories translated into English provides students with language skills and areas development and a better understanding of their own culture as well. Since a local short story excludes complicated expressions (idioms, slang, etc.) and language patterns, students will find it much easier to cover. Some other benefits of using local short stories are cultural conflict prevention, cultural values, and identities implantation. To guarantee that students do not miss the opportunity for developing intercultural awareness, however, using local and native short stories interchangeably is highly recommended. By doing so, students will have an opportunity to compare local values and foreign values (Alamsyah, 2016).

Similar to Alamsyah (2016), Yurtbaş1 (2016) believes that using the English version of local short stories, especially the popular ones, is very effective to facilitate students' language skills development and help inculcate a better understanding of their own culture as well. He describes that popular stories like the Turkish Dede Korkut's tales are the potential to use to increase students' speaking skills by exploiting them to provide pronunciation practices. He believes that to speak effectively in English, one should master the English sounds and intonation patterns meticulously. Students' familiarity with the short story can help them practice pronunciation with fun. He accentuates that stories "can be used not only for its inspiration but also for oral practice purposes in English pronunciation classes" (Yurtbaşı, 2016, p. 32).

\section{Teaching Methods/Strategies and Learning Activities and for Using Short Stories}

The fourth theme of the findings in this study concern with learning activities and teaching methods/strategies for using short stories in the EFL classroom. It answers the fifth research question: "What do these articles reveal about the methods, strategies, and activities for using short stories in the EFL classroom?" Five subthemes contribute to this theme: pre-, while, and post-reading method, linguistic and literary analysis technique, short story based language teaching (SSBLT), task-based extensive reading teaching approach, critical thinking strategies to teach short stories, and eclectic and practical activities for exploiting short stories,

The pre-reading, while-reading, and post-reading method is proposed by Tso (2014) based on the reader-response approach to make the class enjoyable and meaningful. The method is described by presenting a model using Grimm's Snow White and the Seven 
Dwarfs he ever applied at a university. The pre-reading stage begins by asking the students to watch a short clip extracted from a movie of the tales to refresh their memory about it. Then students work in pairs to share and make notes of the impressions of the tales, during which the students question and answer each other. Next, students are assigned to have a close reading and then write a summary of the tale. After that, the students work in a small group and discuss the tale by asking thought-provoking questions. The while-reading may be ended with each group presentation. The postreading stage is conducted by assigning them to rewrite or interpret a shelf chosen tale.

The linguistic analysis and literary analysis method focus on reading but later is integrated with the other three language skills and could be set in pre-intermediate to advanced levels (Kaya, 2014; Turan, \& Colak, 2018). The linguistic analysis is conducted in three stages: pre-reading, while-reading, and post-reading. The pre-reading starts with warm-up activities in which students orally discuss the title of the story. Then the students are assigned to have a close-reading of the story once or twice. It can be followed by various activities depending on the class levels. Pre-intermediate students may be asked to listen to the teacher reading the story aloud. One or two students are asked voluntarily to read some parts of the story aloud. The next activity can be a discussion for getting the meanings of unfamiliar words. Upper-intermediate or advanced class can be assigned to discuss the story employing comprehension and inference questions followed by a small group discussion on grammatical or morphological aspects of the story. In the postreading stage, students may be assigned to rewrite some sentences using 'If', transform active sentences into passive sentences (or vice versa), transform some dialogues into a paragraph, etc.

The literary analysis is conducted after the linguistic analysis. It is directed to lead the students to explore the elements of the short story, i.e. plot, character, theme, etc. (Turan, \& Colak, 2018). This stage begins by introducing the elements one by one. After that, the students work in a small group and analyze the short story element by asking relevant questions, such as: Who is the main character of the story? Why do you think so? Can you describe his/her personality? What do you like/dislike about him/her? Does the story have minor, flat, and round characters? Where and when the story is set? What is the theme? The literary analysis can be ended by assigning the students to write an analysis on one or more of the short story elements.

Short Story Based Language Teaching (SSBLT) is a humanistic literature-based language teaching method aiming to promote the students personal, cultural and linguistic awareness. The objective of this method is to help learners to learn and use language for communication and hone critical thinking using short stories in a friendly atmosphere (Khatib \& Seyyedrezaei, 2017). This method is conducted in three stages: pre-reading, while-reading, and post-reading. The pre-reading stage is set to provide introductory information about the short story and the objectives of studying it. The while reading stage for the pre-intermediate level could be done by asking students to listen while the teacher reads the story slowly and clearly, employing proper intonation, gestures, and facial expressions to help students follow the story. During the reading, students are asked questions about the characters and what will happen next to makes the students active. In intermediate or higher levels, students are assigned to close read the story. After that, students can discuss unfamiliar expressions they encounter. In the postreading stage, students are asked to work in groups in which they ask and answer factual, referential, inferential, and evaluative questions. After that, they discuss and summarize the story, paraphrase one or more paragraphs, write about the theme, and so on. 
The Task-Based Extensive Reading Teaching Approach was heavily drawn by Rabbidge (2013) on Extensive Reading (ER) ideas and graded reading materials that have been successfully used in a teacher training program in South Korea. Short stories in the materials can be covered in two or three class periods, during which certain aspects of the short story are explored to help students develop a greater appreciation of the short story they are studying. Since the stories are graded, teachers can easily select ones that suit the students' proficiency levels. Each class session is divided into three stages: pre-reading, while-reading, and post-reading. In the pre-reading stage, the short story's key themes, vocabulary, and characters are introduced by employing various available relevant media, such as pictures, sketches, etc. the stage ends by arousing students' curiosity to increase their eagerness to read the story. In the while-reading stage, students do a silent reading of half of the story in about 15-20 minutes, during which they are encouraged to use the story's context to guess the meaning of unfamiliar words - if any. In the post-reading stage, students reflect and respond personally to the story by asking them to discuss different elements of the story with their peers. If a story is covered in two sessions, the second session's pre-reading stage begins by asking the students to review what they have learned so far. This could be done by letting them watch the short story's movie version and then track the characters' mood changes. It is followed by warm-up activities intended to enlarge the students' knowledge of the story. Prediction activities using use a series of pictures to predict the remainder of the story are recommended in this stage. Like the first session, in the while-reading stage, the students do a silent reading of the remainder of the story, but now students should check the predictions they previously made. The post-reading stage is used to let students reflect and respond by discussing whether their predictions are close enough to the story's actual outcome. This stage can also be used to ask students to do a role play which allows them to further explore the story.

The Critical Thinking Strategies on Teach Short Stories was proposed by Thapaliya (2012) based on his experience of employing those techniques in teaching short stories in EFL classrooms in Nepal. Each class session of the method is divided into three stages: anticipation phase, building knowledge phase and consolidating phase. The strategies employed in the anticipation phase include a structured overview, predicting from terms, think-pair-share (T-P-S), and know-want-to-know-learn (K-W-L). The building knowledge phase employs Directed reading activity (DRA) and paired reading and summarizing strategies. The consolidating phase employs T-P-S, value line, and quick reading and quick writing (QRQW) strategies. Since this method employs strategies based on a student-centered approach that boosts students' engagement, Thapaliya (2012) believes that the usage of Critical Thinking Strategies to teach short story "can make students more creative, active, innovative, critical, analytical and constructive" (p. 101).

Different from the authors above who propose specific teaching methods/strategies for teaching short stories, Pardede (2011) and Yunita and Machdarifah (2018) suggest implementing eclectic and practical activities for exploiting short stories. Pardede (2011) believes that every teaching situation is unique so that there is no single method that befits EFL learning and teaching using short stories. So, to optimize short story exploitation, teachers need to devise various kinds of activities to provide various learning styles for optimizing learning outcomes. For instance, to develop their vocabulary, students can be assigned to deal with vocabulary exercises while or after reading a short story. To facilitate this, teachers take some words from the short story and devise part of speech practices, matching words with their meanings or definition, filling in blanks with correct

Pardede: A Review of Current Conceptual Research on Short Stories Use in EFL Classrooms DOI: https://doi.org/10.33541/jet.v7i1.2595 
word forms. For students in upper-intermediate and advanced levels, reading activities could be combined with guessing meaning using contexts and sharing ideas with peers. To develop writing skills, after reading a short story, students are assigned in pairs or small groups to convert a paragraph into a dialogue, to paraphrase one or two paragraphs, to write a reader response, analyze the short story elements, etc. To develop listening and speaking, teachers can assign the students to listen to the recording version of the story (or teachers read the story aloud), students retell the story as a chain activity in small groups, students debate controversial issues in the story, or students make a role play based on the short story.

The findings and discussion above show that numerous studies investigating the benefits and effectiveness of short stories use, criteria for selecting short stories that meet students' need and interest, issues on using local short stories instead of native ones, and teaching methods, strategies, and activities for using short stories in EFL classroom have been conducted. The findings and discussion above show that the 14 reviewed articles managed to provide answers to the research questions addressing these issues. The results of these studies will certainly expand our understanding of various aspects related to short story use in EFL classrooms. Hopefully, these studies also provide more insights and ideas to EFL teachers.

However, some other aspects of short stories use in EFL classrooms are not yet appropriately researched. One of them concerns with the difficulties encountered by EFL teachers while using short stories use in the classroom. The findings and discussion above show that the second question, "What do these articles reveal about the difficulties encountered in using short stories in EFL classroom?" is not answered. This indicates that previous studies focusing on teachers' difficulties in using short stories in EFL classrooms are still so meager that writers found insufficient research reports to review the issue. The second crucial issue that is absent from the 14 reviewed articles is related to the use of e-learning in EFL learning and teaching using short stories. The advancement of ICT and its accelerating penetration into the field of education have revolutionized education in general and the EFL field in particular. EFL scholars and practitioners should anticipate it by carrying out research.

Therefore, the obstacles of using short stories in EFL classrooms and ICT use in EFL learning using short stories are some of the important issues future studies should focus on.

\section{CONCLUSIONS AND RECOMMENDATION}

Conceptual papers on short stories use in EFL classrooms published in 2011 to 2020 reveal that the aspects concerning the benefits and effectiveness of short stories use, criteria for selecting short stories that meet students' need and interest, issues on using local short stories instead of native ones, and teaching methods, strategies, and activities for using short stories in EFL classroom have been quite rigorously studied. Two urgent issues future research needs to focus on are obstacles encountered by teachers in using short stories and ICT use in EFL learning using short stories.

This study reviewed only conceptual papers accessible on the Google Scholar site. Future reviews are recommended to include relevant thesis and dissertations not yet indexed by Google Scholar. Reviewing empirical research reports on short stories use in EFL classrooms is also recommended. 


\section{REFERENCES}

Alamsyah, A. (2016). The Use of Local Short Story in English Language Learning (A Literary Review on the Use of Local Sources as an Alternative Teaching Media in EFL). Konferensi Linguistik Tahunan Atma Jaya 14. Retrieved January 2021 from https://files.eric.ed.gov/fulltext/ED577317.pdf

Berrarbi, A. \& Bahous, A. (2018). Introducing Short Stories in EFL Classroom to Explore Culturally Diverse Issues. AWEJ for Translation \& Literary Studies, 2(2), 103-116

Bretz, M. L. (1990). Reaction: Literature and communicative competence: A springboard for the development of critical thinking and aesthetic appreciation. Foreign Language Annals, 23(4), 335-338

Collie, J., \& Slater, S. (1991). Literature in the language classroom. (5th ed.). Glasgow: Cambridge University Press

Ganakumaran, S., Shahizah, I.H. \& Koo, Y.L. (2003) Pedagogical implications of the incorporation of the Literature Component in the Malaysian ESL syllabus. In Ganakumaran S. (Ed) The Malaysian ESL syllabus in teaching of literature in ESL/EFL contexts. (62-87). Sasbadi, Petaling Jaya: Malaysia

Ghosn, I. (2002). Four Good Reasons to Use Literature in Primary School. ELT Journal, $56(2), 172-179$.

Kaya, S. Ü. (2014). Using Short Stories in ELT/EFL Classes. Başkent University Journal of Education, 1(1), 41-47

Krishna, T.M. \& Sandhya, K. (2015). The Impact of Short Stories on Teaching of English. Veda's Journal of English Language and Literature- JOELL, 2(4), 58-62

Khatib, M. \& Seyyedrezaei, S.H. (2017). Short Story Based Language Teaching (SSBLT): A literature-based Language Teaching Method. Journal of Humanities Insights, 1(4): 177-182

Kolb, S. M. (2012). Grounded Theory and the Constant Comparative Method: Valid Research Strategies for Educators. Journal of Emerging Trends in Educational Research and Policy Studies (JETERAPS), 3 (1), 83-86

Liu, L. (2003). A New Perspective on the Goals of TEFL in China. A New Perspective on the Goals of TEFL in China. The Internet TESL Journal, 9(11). Retrieved June 2015 from http://iteslj.org/Articles/Liu-Goals.html

Modern Language Association of America. (2007). Foreign Languages and Higher Education: New Structures for a Changed World (2007). Retrieved June 2018 from http://www.mla.org/pdf/forlang_news_pdf.pdf.

Pardede, P. (2011). Using Short Stories to Teach Language Skills. Journal of English Teaching, 1(1), 14-27.

Parkinson, B. \& Reid-Thomas H. (2000). Teaching literature in a second language. Edinburgh: Edinburgh University Press.

Pathan, M. M. (2013). Use of Short Stories in EFL Classroom: Advantages and Implications. Labyrinth: An International Refereed Journal of Postmodern Studies, 4 (2), 21-26.

Rabbidge, M. (2013). Approaches to Using Short Stories in the EFL classroom. In Proceedings of the Second World Congress on Extensive Reading Seoul, Korea, September 13-15, 2013, pp. 262-269

Saha, S. (2014). Addressing the Unaddressed: Considering Specific Teaching Context to Teach Language to EFL Learners through Literature. Language in India 14(7), 528545 
Savvidou, C. (2004). "An Integrated Approach to the Teaching of Literature in the EFL Classroom." The Internet TESL Journal, 10(12) Retrieved July, 2010, from http://iteslj.org/Techniques/Savvidou_Literature.html

Sell, J.P.A. (2005). Why teach literature in the foreign language classroom? Encuentro 15(1): 86-93.

Sholichah, I.R. \& Purbani, W. (2018). Fostering Language Skills Development through Fairy Tales: A Literature Study. Advances in Social Science, Education and Humanities Research, Vol. 165, pp. 330- 334.

Thapaliya, M.P. (2012). Teaching Short Story through Critical Thinking (CT) Strategies. Journal of NELTA, 17(1-2), 93-103

Tso, A.W.B. (2014). Teaching Short Stories to Students of English as a Foreign Language (EFL) at Tertiary Level. Journal of Language and Linguistic Studies, 10(1), 111117.

Tucker, G.R. \& W.E. Lambert (1972).Sociocultural Aspects of Foreign-Language Study. Dodge, J. W. (ed.), Northeast Conference Reports. Montpellier: The Capital City Press, Vermont.

Turan, Y.Z. \& Colak, R. (2018). The Use of Short Story as a Learning/Teaching Tool in ELT/EFL Classes: "The Necklace" By Guy De Maupassant. Karabük Üniversitesi Sosyal Bilimler Enstitüsü Dergisi, 8(1), 173-189

Yunita, R. \& Machdarifah, I. (2018). The Application of Short Stories in Teaching English. In Proceeding International Seminar and Annual Meeting BKS-PTN Wilayah Barat, 1(1), 610-614

Yurtbaş1, M. (2016). Dede Korkut's tales can inspire the Turkish ESL students to speak better. English. Journal of Bayburt Education Faculty, 11 (1), 22-34 
Appendix

\section{List of the Selected Conceptual Papers}

\begin{tabular}{|c|c|c|}
\hline No & Research & Focus \\
\hline 1 & $\begin{array}{l}\text { Yunita \& } \\
\text { Machdarifah (2018) }\end{array}$ & $\begin{array}{l}\text { - Why SSs are the best to use in EFL classrooms } \\
\text { - Activities for using SS to develop language skills and critical } \\
\text { thinking, motivate students to learn literary aspects, and } \\
\text { integrate cultural awareness. }\end{array}$ \\
\hline 2 & $\begin{array}{l}\text { Turan, \& Colak. } \\
\text { (2018) }\end{array}$ & $\begin{array}{l}\text { - Advantages of SSs use } \\
\text { - How to choose SSs. } \\
\text { - Techniques for using SSs: linguistic and literary analysis }\end{array}$ \\
\hline 3 & $\begin{array}{l}\text { Sholichah \& Purbani } \\
\text { (2018). }\end{array}$ & $\begin{array}{l}\text { Benefits for using fairy tales (as a type of SSs) to develop EFL } \\
\text { young learners' language skills }\end{array}$ \\
\hline 4 & $\begin{array}{l}\text { Khatib \& } \\
\text { Seyyedrezaei (2017) }\end{array}$ & $\begin{array}{l}\text { - Importance and benefits of using SSs } \\
\text { - Introduction to SSs-Based Language Teaching (SSBLT) as } \\
\text { a teaching method. }\end{array}$ \\
\hline 5 & Alamsyah (2016) & $\begin{array}{l}\text { Major issues in using local vs. native SSs in EFL classrooms in } \\
\text { Indonesian context }\end{array}$ \\
\hline 6 & Yurtbaşı (2016) & $\begin{array}{l}\text { Methods for improving English pronunciation using Dede } \\
\text { Korkut's tales (as a type of SSs) to explore Turkish culture and } \\
\text { improve English Turkish EFL learners' speaking skills. }\end{array}$ \\
\hline 7 & $\begin{array}{l}\text { Krishna \& Sandhya } \\
(2015)\end{array}$ & $\begin{array}{l}\text { Why SSs are the best to use to develop language skills and } \\
\text { vocabulary and promote literary, cultural, and higher-order } \\
\text { thinking aspects. }\end{array}$ \\
\hline 8 & Kaya (2014) & $\begin{array}{l}\text { - Advantages of using SSs in ELT/EFL classes } \\
\text { - A lesson model of activities for exploiting a SS to develop } \\
\text { language skills }\end{array}$ \\
\hline 9 & Saha (2014) & $\begin{array}{l}\text { - Significances of using SSs } \\
\text { - Description of some main literature-based language tasks for } \\
\text { teaching language skills to EFL tertiary level students }\end{array}$ \\
\hline 10 & Tso (2014) & $\begin{array}{l}\text { Methodological strategies and a model for using short stories for } \\
\text { students' language skills development and students' cultural and } \\
\text { critical literacies cultivation. }\end{array}$ \\
\hline 11 & Rabbidge (2013) & $\begin{array}{l}\text { Ideas for using task-based, extensive reading teaching } \\
\text { approaches to facilitate integrated language skills learning and } \\
\text { practices in EFL classes. }\end{array}$ \\
\hline 12 & Pathan (2013) & $\begin{array}{l}\text { Multidimensional benefits of using SSs in EFL classrooms, and } \\
\text { their implications in EFL context. }\end{array}$ \\
\hline 13 & Thapaliya (2012) & $\begin{array}{l}\text { Using critical thinking strategies to provide more creative, } \\
\text { active, innovative, critical, analytical, and constructive student- } \\
\text { centered learning using short stories in particular. }\end{array}$ \\
\hline 14 & Pardede (2011) & $\begin{array}{l}\text { - Main issues SSs use effectiveness in EFL instruction } \\
\text { - How to select SSs. } \\
\text { - Some effective learning activities for exploiting a short story } \\
\text { to develop EFL learners' language skills. }\end{array}$ \\
\hline
\end{tabular}

